\title{
Strategi Penataan Pedagang Kaki Lima (PKL) Berdasarkan Pola Aktivitas dan Pola Penyebarannya di Koridor Jalan Pejanggik Kecamatan Cakranegara
}

\author{
*Baiq Siti Noer Azima, Ardi Yuniarman, Sri Apriani Puji Lestari \\ Teknik Perencanaan Wilayah dan Kota, Universitas Muhammadiyah Mataram \\ Azima.noer@gmail.com*
}

\begin{tabular}{l} 
INFO ARTIKEL \\
Riwayat Artikel: \\
Diterima: 05-03-2020 \\
Disetujui: 08-05-2020 \\
\hline
\end{tabular}

Kata Kunci:

Strategi

Penataan PKL

Pedagang Kaki Lima

Sektor Informal

Pola Sebaran

\begin{abstract}
ABSTRAK
Abstrak: Koridor Jalan Pejanggik sebagai salah satu koridor utama di Kota Mataram, aktifitas utamanya sangat dipengaruhi oleh kegiatan komersial baik perdagangan formal maupun informal. Sektor perdagangan informal selain memberi dampak secara positif dan dampak negatif bagi kawasan tersebut. Pedagang Kaki Lima menempati pedestrian hingga bahu jalan yang mengakibatkan peralihan ruang aktifitas pejalan kaki ke bahu jalan ditambah kurangnya lahan parkir yang memadai, memberikan dampak berupa kurangnya sirkulasi pada kendaraan yang melewatinya. Tujuan penelitian ini yaitu untuk mengetahui pola aktivitas dan pola penyebaran pedagang kaki lima serta strategi penataan pedagang kaki lima berdasarkan pola aktivitas dan pola penyebarannya. Metode analisis yang digunakan berupa deskriptif kualitatif berdasarkan hasil wawancara, observasi, studi pustaka dan dokumentasi serta menggunakan rumus SWOT dalam menentukan strategi penataannya. Hasil analisa menunjukkan bahwa setiap aktivitas pedagang kaki lima dipengaruhi oleh hubungan langsung atau tidak langsung dengan aktivitas formal di koridor jalan tersebut serta aktivitas ini dipengaruhi oleh waktu berdagangnya. Adapun pola penyebarannya cenderung linier mengikuti pola jalan. Strategi penataan koridor dilakukan dengan mengatur pola parkir, jenis, waktu dan desain sarana usaha pedagang kaki lima. Dalam perencanaan tata ruang Kota Mataram, perlu mengakomodir ruang aktivitas PKL nya, tidak hanya merencanakan lokasi penempatan PKL.
\end{abstract}

\begin{abstract}
Pejanggik Road Corridor as one of the main corridors in Mataram City, Its main activities are heavily influenced by formal such as informal commercial and trade activities. The informal trade sector in addition to positively impacts and negative impacts on the region. Street vendors occupy a pedestrian walk to the shoulder leading to a pedestrian space shifting to the street plus a lack of adequate parking space, impacting the lack of circulation in vehicles passing through them. The purpose of this research is to know the patterns of activity and patterns of spread of street vendors and the arrangement strategies of street vendors based on activity patterns and spread patterns. The method of analysis used is a qualitative descriptive based on the results of interviews, observations, library studies and documentation as well as using the SWOT formula in determining the strategy of the arrangement. The results of the analysis show that every street merchant activity is influenced by a direct or indirect relationship with formal activity in the corridor and this activity is influenced by its trading time. As for the spread pattern it tends to linear following the road pattern. The corridor Setup strategy is done by arranging the parking pattern, type, time and design of the street Hawker Business. In the spatial planning of the City of Mataram, it is necessary to accommodate the space of its street vendors activities, not only to plan the location of the street vendors placement.
\end{abstract}

\section{A. LATAR BELAKANG}

Koridor jalan merupakan ujung tombak identitas pengenal dalam sebuah kawasan dikarenakan karakteristik visualnya yang paling mudah dibaca oleh pengguna jalan. Aspek yang dilihat pengguna tidak hanya dari segi bentuknya saja tetapi dari aktivitas yang dilakukan oleh manusia di dalamnya (Rizky, 2015).
Koridor Jalan Pejanggik merupakan jalan kolektor 3 dengan tingkat kepadatan yang cukup tinggi di Kota Mataram. Berdasarkan Rencana Tata Ruang dan Wilayah (RTRW) Kota Mataram tahun 2009-2029, koridor Jalan Pejanggik yang berada di Kecamatan Cakranegara yang merupakan kawasan ekonomi diperuntukkan bagi perdagangan dan jasa / komersial. Adanya aktivitas perdagangan dan jasa / komersial pada Koridor Jalan Pejanggik ini turut memberikan dampak positif maupun 
negatif bagi pengguna dan koridor itu sendiri. Salah satu dampak positifnya adalah meningkatnya perekonomian masyarakat sekitar karena memberikan berbagai peluang usaha, mulai dari pedagang-pedagang kecil sampai komplek pertokoan modern ataupun department store. Sedangkan dampak negatif yang timbul diantaranya adalah yang timbul diantaranya adalah peralihan fungsi jalur pedestrian yang ditempati Pedagang Kaki Lima dan parkir liar, serta berkurangnya ruang terbuka yang dimiliki oleh pejalan kaki akibat peralihan fungsi jalur yang diakibatkan oleh adanya Pedagang Kaki Lima.

Jalan Pejanggik merupakan salah satu lokasi penataan pedagang kaki lima sesuai dengan arahan yang tercantum dalam Perda Kota Mataram Nomor 12 Tahun 2011 Tentang Rencana Tata Ruang Wilayah Kota Mataram. Namun, hingga saat ini, pedagang kaki lima masih menjadi permasalahan yang ada di koridor Jalan Pejanggik. Dilihat dari kondisi eksisting koridor Jalan Pejanggik memiliki aktivitas lalu lintas yang cukup ramai yang merupakan tempat berlangsungnya kegiatan sektor formal, sehingga hal ini dimanfaatkan oleh para Pedagang Kaki Lima dalam strategi pemasarannya.

\section{B. METODE PENELITIAN}

Pendekatan penelitian yang digunakan pada penelitian ini adalah pendekatan deskriptif kualitatif. Pengumpulan data dilakukan melalui observasi lapangan, dokumentasi dan wawancara terhadap responden dengan sampel 76 pedagang yang terbagi menjadi 5 responden berdasarkan jenis dagangan yakni makanan/minuman sebanyak 57 orang, aksesoris/mainan anak 1 orang, rokok/makanan ringan 6 orang, barang cetakan 7 orang dan kios sebanyak 1 orang. Observasi dan wawancara ditujukan unutk memperoleh gambaran pemetaan terhadap pola aktivitas pedagang kaki lima dan pola penyebarannya. Hasil data observasi dianalisis dengan pendekatan analisis SWOT untuk menghasilkan rumusan strategi penataan pedagang kaki lima.

\section{HASIL DAN PEMBAHASAN}

1. Gambaran Umum Koridor Jalan Pejanggik

Lokasi penelitian ini berada di koridor Jalan Pejanggik yang berada di kawasan ekonomi Cakranegara dan secara administrasi berada di garis batas antara Kelurahan Cakra Barat dan Kelurahan Cilinaya. Koridor Jalan Pejanggik ini memiliki panjang $1,3 \mathrm{~km}$ yang merupakan kawasan perdagangan dan jasa. Dengan batas administrasi wilayah perencanaan ialah sebagai berikut:

Utara : Jl. Kebudayaan (Kelurahan Cakra Barat)

Barat : Jl. Pejanggik dan Jl. Bung Hatta

Selatan : Jl. Panca Usaha (Kelurahan Cilinaya)

Timur: Jl. A.A. Gede Ngurah dan Jl. Selaparang

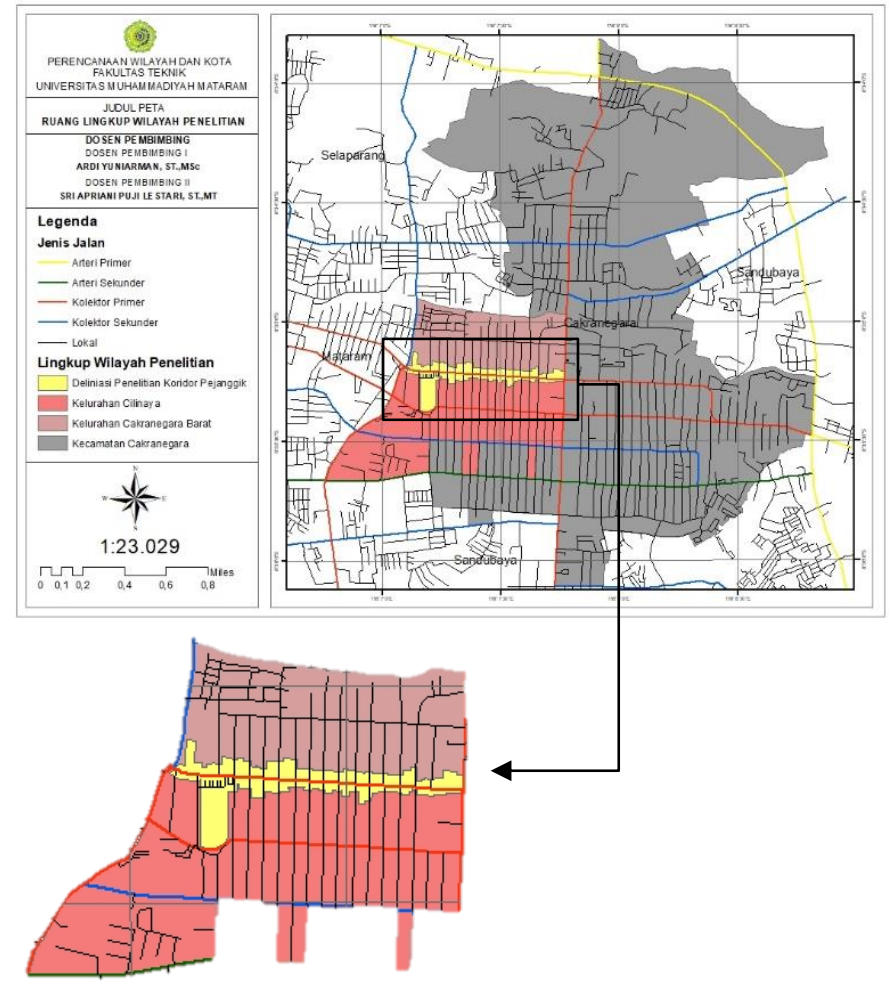

Gambar 1. Peta Deliniasi Koridor Jalan Pejanggik

2. Pola Aktivitas dan Pola Penyebaran PKL

a. Pola Aktivitas

1) Lokasi Berdagang

Lokasi yang paling diminati oleh PKL untuk berdagang yaitu menempati ruang yang dirasa cukup untuk membuka lapak dagangan serta berada berdekatan dengan pusat perdagangan dan jasa, sarana pendidikan dan sarana kesehatan (yang memiliki aktivitas tinggi).

Lokasi-lokasi tersebut merupakan lokasi kegiatan komersial yang letaknya berdekatan dalam suatu kawasan ekonomi, maka dengan sendirinya akan menjadi suatu daya tarik yang kuat untuk dikunjungi oleh konsumen yang menimbulkan akumulasi pengunjung/pergerakan pengunjung pada ruang penghubung antar kegiatan tersebut.

Pada sisi kiri koridor Jalan Pejanggik memiliki beberapa kegiatan yang berbeda yaitu perdagangan dan jasa, pendidikan, dan kesehatan mengakibatkan tidak adanya jalur yang menerus antar kegiatan yang ada. Atau dapat dikatakan bahwa jalur perdagangan antara sisi kiri dan sisi barat terputus dengan adanya sederetan kegiatan yang berbeda, sehingga pengunjung tidak seramai di bagian kiri atau akumulasi pengunjung rendah pada bagian kanan. Hal ini juga dikarenakan pada bagian sisi kanan masih adanya kegiatan perdagangan-jasa hingga malam hari, sehingga tidak adanya ruang untuk lokasi berdagang PKL. 


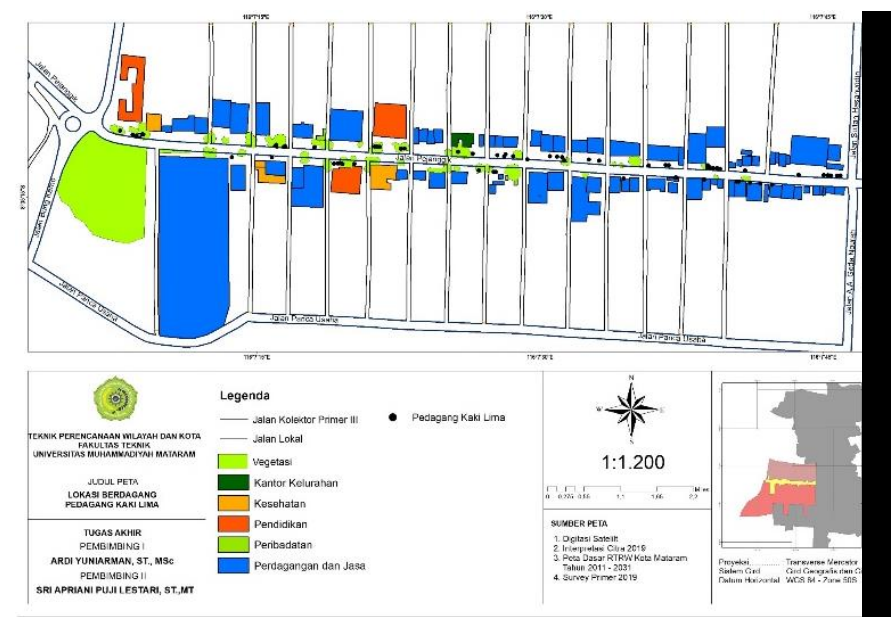

Gambar 2. Peta Lokasi Berdagang PKL di Koridor Jalan Pejanggik Kecamatan Cakranegara

2) Waktu Berdagang

Menurut waktu berdagangnya, aktivitas Pedagang Kaki Lima terbagi menjadi dua dalam satu hari yakni pagi sampai dengan siang (jam 07.00 - 15.00) dan sore sampai dengan malam hari (15.00 - oo.0o).

waktu berdagang PKL pada sore hingga malam hari sangat mempengaruhi lokasi dan keberadaan PKL. Karena, pada waktu sore s/d malam hari aktivitas formal sudah mulai tutup sehingga PKL dapat memanfaatkan ruang yang ada untuk melakukan aktivitas berdagangnya. Pada waktu pagi hingga siang hari ketika aktivitas perdagangan dan jasa berlangsung (buka), pedagang kaki lima memanfaatkan trotoar (pedestrian ways) sebagai lapak berjualan, namun ketika aktivitas perdagangan dan jasa sudah tutup, pedagang memanfaatkan ruang yang ada untuk melakukan aktivitas berdagang. Namun, sebagian besar pedagang sudah melakukan kerjasama atau mendapatkan izin dari pemilik bangunan untuk melakukan aktivitas informal.

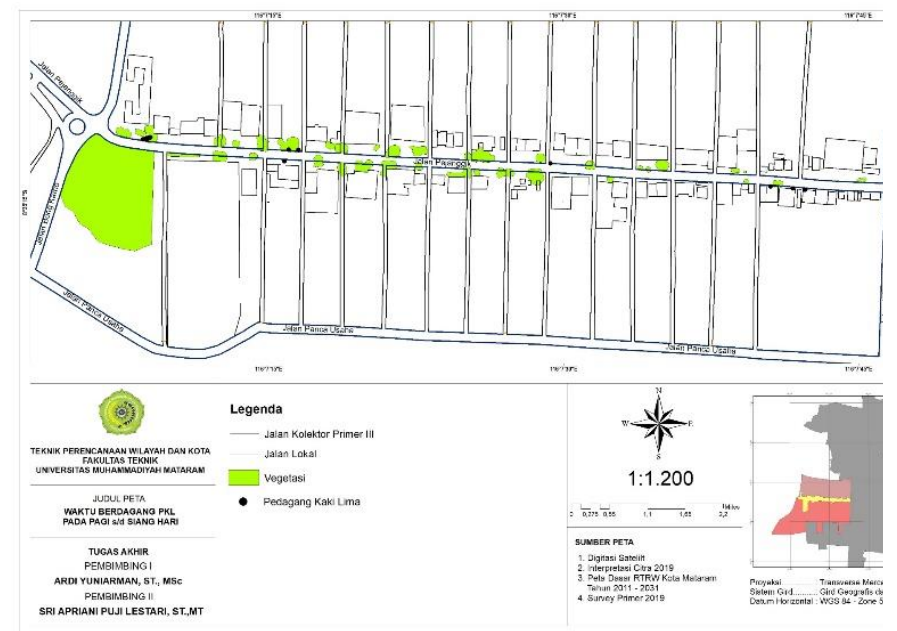

Gambar 3. Peta Waktu Berdagang PKL Pada Pagi Hingga Siang Hari di Koridor Jalan Pejanggik Kecamatan Cakranegara

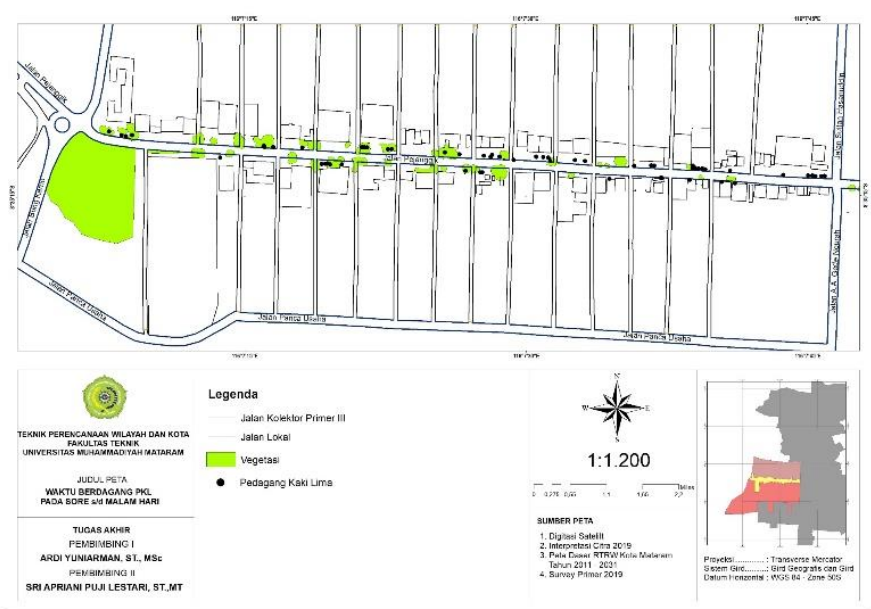

Gambar 4. Peta Waktu Berdagang PKL Pada Sore Hingga Malam Hari di Koridor Jalan Pejanggik Kecamatan Cakranegara

3) Jenis Dagangan dan Sarana Berdagang

Dari tabel diatas, keanekaragaman jenis dagangan PKL yang terdapat di koridor Jalan Pejanggik ini, sesuai dengan karakter PKL, bahwa jenis dagangan PKL selalu mengikuti aktivitas induk yang terdapat di kawasan tersebut., karenanya jenis-jenis dagangan PKL tersebut adalah makanan/minuman, aksesories, kelontong, dll, yang merupakan jenis-jenis dagangan yang terdapat atau diperlukan pada aktivitas perdagangan, perkantoran, kesehatan dan akomodasi, yang terjadi di kawasan ini.

Adapun jenis sarana dagangan yang digunakan para pedagang kaki lima di koridor Jalan Pejanggik, seperti gerobak, tenda (warung semi permanen), meja, rak, lesehan, gelaran dan kereta dorong merupakan sarana yang mudah dan efisien digunakan untuk menggelar dagangannya, sehingga mudah untuk terlihat dan memilih barang dagangan oleh para pengunjung. Jenis-jenis sarana dagangan yang digunakan tersebut mudah untuk dibongkar pasang dan dipindahkan untuk disimpan/dibawa pulang oleh pedagang. Hal ini sesuai dengan peraturan yang berlaku di kawasan tersebut, bahwa setelah waktu berdagang selesai, pedagang tidak boleh meninggalkan sarana dagangan di lokasi dan tempat berdagang PKL atau dengan kata lain lokasi dan tempat dagangan harus bersih tidah ada sarana dagangan yang ditinggalkan pedagang hal ini juga sesuai dengan kesepakatan antara pihak pedangan PKL dengan pihak pemilik bangunan atau lahan yang mereka gunakan untuk melakukan lapak. 


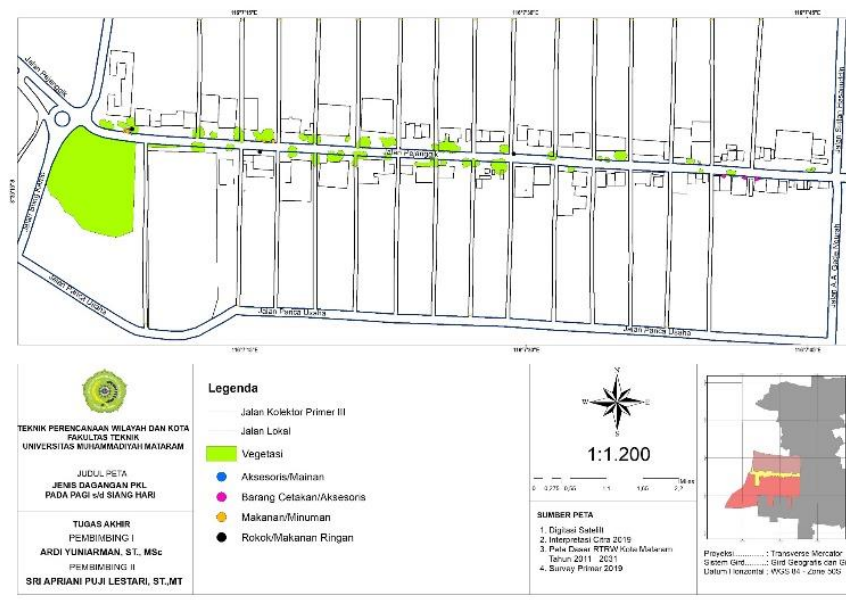

Gambar 5. Peta Jenis Dagangan PKL Pada Waktu Pagi Hingga Siang Hari di Koridor Jalan Pejanggik Kecamatan Cakranegara

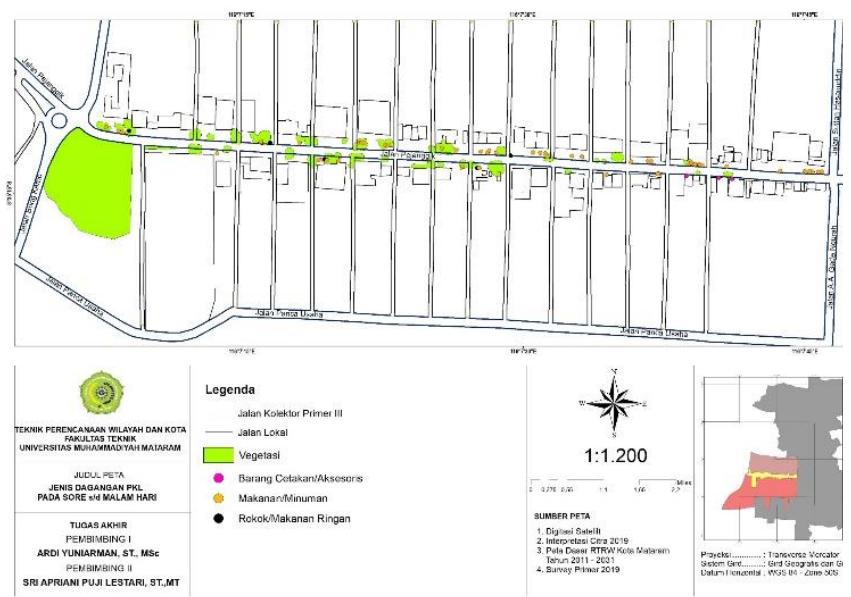

Gambar 6. Peta Jenis Dagangan PKL Pada Waktu Sore Hingga Malam Hari di Koridor Jalan Pejanggik Kecamatan Cakranegara

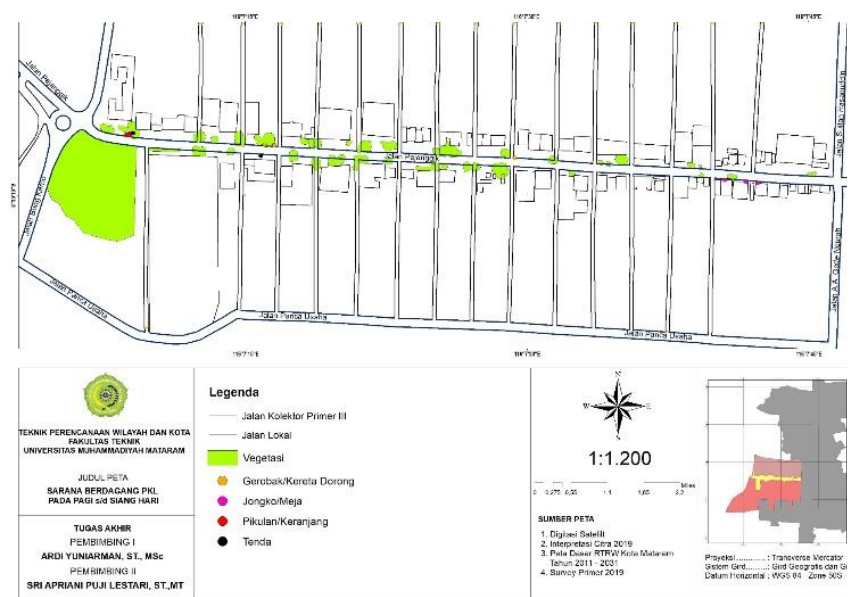

Gambar 7. Sarana Berdagang PKL Pada Waktu Pagi Hingga Siang Hari di Koridor Jalan Pejanggik Kecamatan Cakranegara

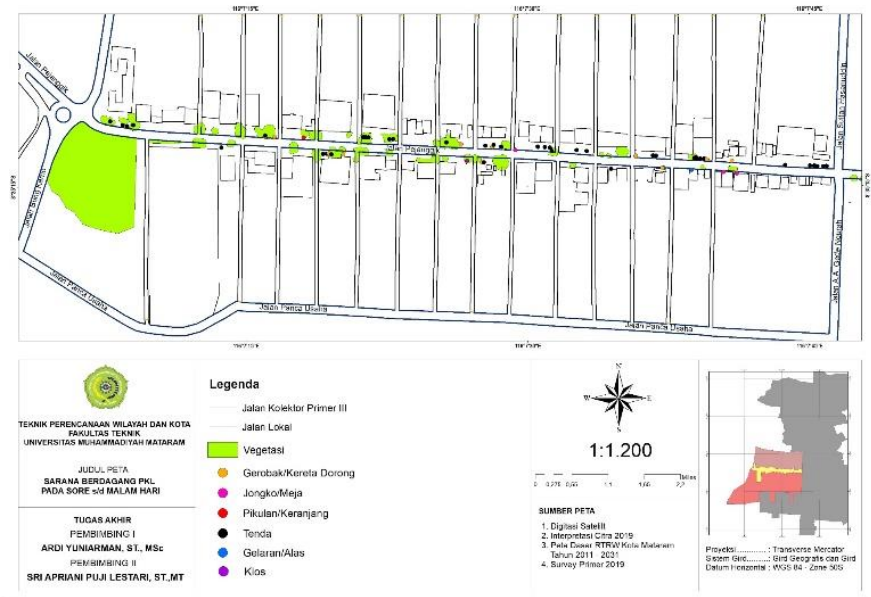

Gambar 8. Sarana Berdagang PKL Pada Waktu Sore Hingga Malam Hari di Koridor Jalan Pejanggik Kecamatan Cakranegara

b. Pola Penyebaran

Pola penyebaran pedagang kaki lima (PKL) dapat dilihat dari pola aktivitasnya yakni memanjang (linier) mengikuti pola jalan.

Pola penyebaran PKL ini terjadi di mulai dari pintu masuk koridor Jalan Pejanggik hingga pintu keluar koridor. PKL ini berderet memanjang mengikuti pola trotoar yang lurus mengikuti pola jaringan jalan adalah merupakan aglomerasi linier. PKL berada di trotoar ini, karena tempat tersebut cukup ramai dilalui pengunjung atau pejalan dan mudah terlihat dari kendaran yang lalu lalang. Hal ini menjadikan daya tarik para PKL untuk beraktivitas dan beraglomerasi menjajakan dagangannya, karena dapat dengan mudah dicapai dan dilihat oleh pengunjung baik yang berada di trotoar maupun pengunjung yang melintas di jalan raya/pengunjung yang berkendaraan. Untuk lebih jelasnya dapat dilihat pada gambar dibawah ini.
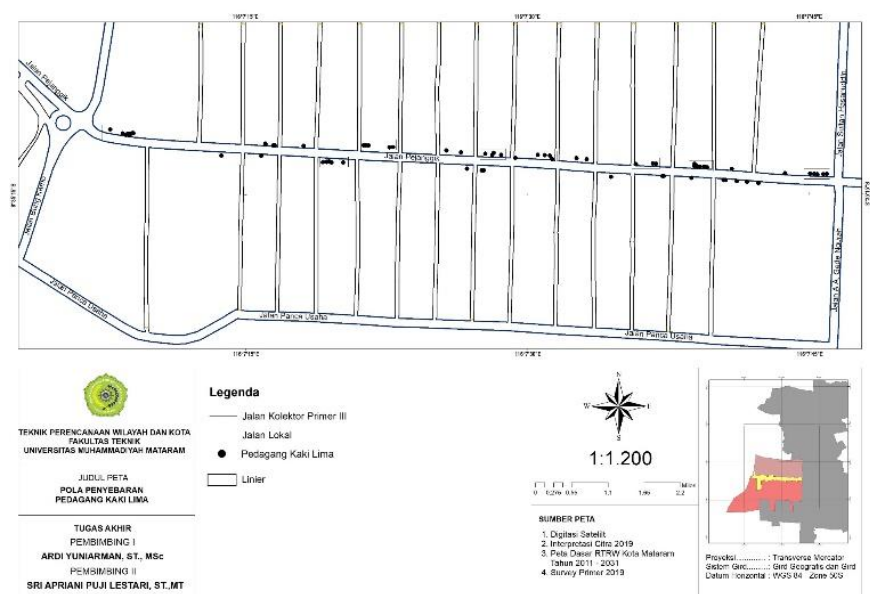

Gambar 9. Peta Pola Penyebaran PKL di Koridor Jalan Pejanggik Kecamatan Cakranegara

3. Strategi Penataan PKL Berdasarkan Analisis SWOT

Dari hasil observasi dan pemetaan pada koridor Jalan Pejanggik, maka dilakukan identifikasi terhadap kekuatan (strength), kelemahan (weakness), peluang (opportunity) dan ancaman (threat). Adapun kekuatan (strength) yang dimiliki saat ini ialah: 
a) Keberadaan PKL meningkatkan ekonomi masyarakat dari sektor informal.

b) Keberadaan PKL menjadi identitas yang menghidupkan kawasan.

c) Kestrategisan Jalan Pejanggik yang merupakan salah satu koridor utama Kota Mataram dan merupakan kawasan ekonomi di Kota Mataram.

d) Jenis dagangan yang beragam, menjadi alternatif tujuan masyarakat Kota Mataram untuk mencari kebutuhan sehari-hari.

e) Harga jual produk dagangan baik kuliner maupun lainnya relatif murah dan dapat dijangkau pembeli kelas menengah ke bawah.

f) Berada di koridor komersial kota dengan sarana penunjang berupa tempat, pendidikan, kesehatan dan perdagangan-jasa.

Sedangkan kelemahan (weakness) ialah:

a) Aktifitas PKL tidak didukung oleh ketersediaan lahan parkir yang mecukupi.

b) Tidak didukung oleh penyediaan street furniture yang memadai, sehingga mengurangi kenyamanan dan estetika ruang kota.

c) Jenis dagangan berupa makanan tidak di dukung dengan aturan pola kegiatan dan penyediaan prasarana pendukung, sehingga aktifitas memasak dan mencuci bekas alat makan yang dilakukan di tempat merusak estetika koridor.

d) Pihak pemerintah belum memberikan solusi dan inovasi terkait dengan permasalahan yang ada. e) Aktifitas PKL yang berada di pedestrian dan bahu jalan mengganggu aktifitas pejalan kaki, parkir dan pengguna jalan.

Untuk peluang yang mendukung penataan koridor Jalan Pejanggik diantaranya adalah:

a) Adanya kebijakan pemerintah daerah tentang Penataan Pedagang Kaki Lima yang termuat dalam Peraturan Daerah Kota Mataram Nomor 12 Tahun 2011 tentang Rencana Tata Ruang Wilayah Kota Mataram Tahun 2011-2031.

b) Adanya kebijakan khusus pemerintah Kota Mataram yakni Perda Kota Mataram No 10 Tahun 2015 tentang Pedagang Kaki Lima.

c) Pola pikir masyarakat yang semakin praktis.

Sedangkan ancaman terhadap upaya penataan koridor Jalan Pejanggik diantaranya meliputi:

a) Pola pikir pedagang kaki lima tentang penataan masih identik dengan relokasi yang akan merugikan mereka.

b) Pola pikir masyarakat pembeli bahwa dengan tampilan PKL yang lebih baik akan menaikkan harga jual produk dibandingkan sebelumnya.

c) Kebiasaan masyarakat pembeli yang malas untuk berjalan jauh dari titik parkir untuk membeli barang kebutuhan mereka.

d) Beberapa pedagang dengan jenis dagangan yang sama berada di satu titik area.

Berdasarkan hasil analisis SWOT maka dirumuskan beberapa strategi seperti terlihat pada tabel 1 berikut.

Tabel 1. Perumusan Strategi Dalam Matriks SWOT

\section{Opportunity X Strenght}

(Peluang X Kekuatan)

a. (S.1,S.2,S.3,S 6, X O.1,O.2) Melakukan penataan PKL dengan prinsip kemanusiaan, keadilan, kemitraan, kepastian hukum, kejujuran usaha dan persaingan sehat.

b. (S.6 X O.3) Menerapkan konsep simbiosis mutualisme antara kegiatan pertokoan dengan aktifitas PKL.

c. (S.6 X O.2) Memanfaatan bangunan-bangunan kosong yang dapat dialihfungsikan sebagai ruang usaha penempatan PKL.

d. (S.1,S.2 X O.1) Lokasi penempatan titik PKL harus didukung dengan rencana tata ruang dengan melakukan studi kelayakan terlebih dahulu.

\section{Opportunity X Weakness \\ (Peluang X Kelemahan)}

a. (O.1 X W.1, W.5) Menerapkan konsep pengaturan zona parkir pada jam dan zona tertentu sesuai dengan karakteristik aktifitas koridor.

b. (O.1 X W.2) Melengkapi koridor jalan dengan street furniture yang nyaman, estetis dan efektif bagi pengguna.

c. (O.3 X W.3) Desain lapak PKL dilengkapi dengan fasilitas tempat cuci yang langsung terhubung dengan saluran drainase kota.

d. (O.1 X W.2, W.5) Melakukan identifikasi dan relokasi PKL ke ruang potensial lain di sepanjang koridor serta melengkapi dengan sarpras pendukung yang memadai supaya menarik pengunjung.
Threat X Strenght

(Ancaman X Kekuatan)

a. (T.1, T.2 X S.1, S.2, S.5) Rebranding penataan PKL dengan membuat aturan terkait harga jual dagangan yang tetap.

b. (S1, S2 X T.1, T.4) Penataan jenis dan lokasi dagang PKL dengan tetap mempertahankan prinsip partisipatif dan pemberdayaan.

c. (S.6 X T.4) Melakukan identifikasi dan penempatan titik parkir pada berbagai ruang yang memungkinkan untuk dimanfaatkan. 


\section{SIMPULAN DAN SARAN}

1. Simpulan

a. Pola aktivitas PKL tidak terlepas dari pengaruh hubungan langsung dan tidak langsung dengan berbagai kegiatan formal mapun kegiatan informal atau hubungan PKL dengan konsumennya.

b. Lokasi, jenis dagangan maupun sarana berdagangnya dipengaruhi oleh waktu berdagang PKL itu sendiri, hal ini juga dipengaruhi oleh aktivitas formal yang berada di kawasan koridor Jalan Pejanggik.

c. Pola penyebaran PKL yakni berpola linier karena mengikuti pola jaringan jalan serta pola aktivitas PKL yang cenderung berada di sepanjang jaringan jalan dan jalur pedestrian.

d. Strategi penataan PKL berdasarkan analisis SWOT ialah (a)melakukan penataan dengan prinsip kemanusiaan, keadilan, kemitraan, kepastian huku, kejujuran usaha dan persaingan sehat, (b) menerapkan konsep simbiosis mutualisme, (c) memanfaatkan ruang bangunan milik bangunan, (d) lokasi penempatan titik PKL harus didukung dengan rencana tata ruang dengan melakukan studi kelayakan terlebih dahulu

2. Saran

a. Keberadaan PKL di koridor Jalan Pejanggik perlu diakomodasi, aktivitas PKL yang ada merupakan dampak dari adanya aktivitas formal yang di kawasan koridor.

b. Dalam perencanaan tata ruang Kota Mataram, perlu mengakomodir ruang aktivitas PKL nya, tidak hanya merencanakan lokasi penempatan PKL.

c. Dalam menentukan ruang aktivitasnya, harus berdasarkan pola aktivitasnya sendiri dengan mengenali pola sebaran PKL, waktu berdagangnya, jenis dagangannya dan jenis sarana dagangan yang pedagang kaki lima.

\section{DAFTAR RUJUKAN}

[1] Anonim, Rencana Tata Ruang Wilayah Kota Mataram Tahun 2011-2031, Mataram: BAPPEDA Kota Mataram, 2011

[2] Anonim, Perda Kota Mataram Nomor 10 Tahun 2015 Tentang Pedagang Kaki Lima, Mataram: BPPK Kota Mataram, 2015

[3] Prasetyo Tony, D. L., \& Sobri, A, "Evaluasi dan Potensi Pengorasian Bus Sekolah (Studi Kasus: Bus Halokes Poor Town)”, Jurnal Teknik, 2017.

[4] Rizky, S. B, "Pengaruh Kegiatan Komersil Terhadap Kinerja Jalan:Studi Kasus Koridor Jalan Yos Sudarso", Jurnal Arsitektur, Vol 30, 2015.

[5] Shintia Feiby, S. d, "Analisis Perubahan Fisik Kawasan Koridor Jalan Boulevard II Pasca Operasi Jalan”, Jurnal Spasial, 2018.
[6] Syariah Afriani, A. M, "Strategi Penataan Aktivitas Parkir dan PKL Pada Koridor Komersil Kota (Koridor Jalan Gajah Mada Sidoarjo)", Jurnal Arsitektur. 2016.

[7] Widjajanti, R, "Karakteristik Aktivitas Pedagang Kaki Lima Pada Kawasan Komersil di Pusat Kota”, Jurnal Teknik Vol 30, 6. 2015. 